\title{
Erratum
}

\section{Functional analyses of natural killer cells in macaques infected with neurovirulent simian immunodeficiency virus}

Terri M Shieh, Darryl L Carter, R Lee Blosser, Joseph L Mankowski, M Christine Zink, and Janice E Clements Correction to J Neuro Virol 7(1): 11-24.

Upon the examination of the paper, the authors noted that Tables 2 and 3 were incorrect. Corrected versions of Tables 2 and 3 are reproduced here at the request of the authors.

Table 2

\begin{tabular}{llcrc}
\hline $\begin{array}{l}\text { Infection } \\
\text { status }\end{array}$ & $\begin{array}{c}\text { Lesion } \\
\text { severity (n) }\end{array}$ & $\begin{array}{c}\text { CD4+ } \\
\text { lymphocytes } \\
(\%)\end{array}$ & $\begin{array}{c}\text { NK } \\
\text { cells } \\
(\%)\end{array}$ & $\begin{array}{c}\text { Cytotoxic T } \\
\text { lymphocytes } \\
(\%)\end{array}$ \\
\hline Uninfected & None (2) & 86 & $<1$ & 14 \\
SIV-Infected & None (1) & 89 & 0 & 11 \\
SIV-Infected & Moderate (2) & 43 & 10 & 47 \\
SIV-Infected & Severe (3) & 33 & 27 & 40 \\
\hline
\end{tabular}

(n) = number of animals analyzed.
Table 3 SIV-directed lysis by infected macaques

Macaque

SIV-directed killing (percent)

17834

18031

18242

18033

18292

17850

$12 \pm 1.4$

$18 \pm 2.1$

$19 \pm 4.7$

$16 \pm 0.7$

$13 \pm 0.2$

0 